\title{
Ecological Drivers of Species Distributions and Niche Overlap for Three Subterranean Termite Species in the Southern Appalachian Mountains, USA
}

\author{
Chaz Hyseni * (i) and Ryan C. Garrick (1) \\ Department of Biology, University of Mississippi, University, MS 38677, USA; rgarrick@olemiss.edu \\ * Correspondence: chaz.hyseni@gmail.com
}

Received: 1 December 2018; Accepted: 17 January 2019; Published: 21 January 2019

\begin{abstract}
In both managed and unmanaged forests, termites are functionally important members of the dead-wood-associated (saproxylic) insect community. However, little is known about regional-scale environmental drivers of geographic distributions of termite species, and how these environmental factors impact co-occurrence among congeneric species. Here we focus on the southern Appalachian Mountains-a well-known center of endemism for forest biota-and use Ecological Niche Modeling (ENM) to examine the distributions of three species of Reticulitermes termites (i.e., R. flavipes, R. virginicus, and R. malletei). To overcome deficiencies in public databases, ENMs were underpinned by field-collected high-resolution occurrence records coupled with molecular taxonomic species identification. Spatial overlap among areas of predicted occurrence of each species was mapped, and aspects of niche similarity were quantified. We also identified environmental factors that most strongly contribute to among-species differences in occupancy. Overall, we found that $R$. flavipes and $R$. virginicus showed significant niche divergence, which was primarily driven by summer temperature. Also, all three species were most likely to co-occur in the mid-latitudes of the study area (i.e., northern Alabama and Georgia, eastern Tennessee and western North Carolina), which is an area of considerable topographic complexity. This work provides important baseline information for follow-up studies of local-scale drivers of these species' distributions. It also identifies specific geographic areas where future assessments of the frequency of true syntopy vs. micro-allopatry, and associated interspecific competitive interactions, should be focused.
\end{abstract}

Keywords: biodiversity; biogeography; competitive exclusion; ecological niche model; molecular taxonomic identification; PCR-RFLP; Reticulitermes; saproxylic; species richness

\section{Introduction}

\subsection{The Southern Appalachian Mountains: A Center of Endemism for Forest Biota}

The southern Appalachian Mountains, extending latitudinally from northeast Alabama to northwest Virginia, are some of the oldest uplands in North America. These mountains have been exposed and unglaciated for over 100 million years [1]. Steep altitudinal precipitation gradients, a complex heavily dissected topography, and a humid, temperate climate, have shaped southern Appalachian forests into some of the most diverse environments in the eastern United States. [2]. While deciduous oak-hickory forests dominate much of the mid-elevation landscape [2], high elevations (above $1400 \mathrm{~m}$ ) support spruce-fir forests [3], whereas mesic coves support hemlock, and pines are commonly found at xeric low- to mid-elevations [4].

The southern Appalachian Mountains are incredibly rich in biodiversity [5]. The region is thought to have served as a major Pleistocene refuge for numerous species. Past climatic cycles have affected 
distributions of forest biota, resulting in major range shifts or local extinction. Following the Last Glacial Maximum (ca. 21,000 years ago), recolonization is thought to have occurred relatively rapidly, from 7000-16,000 years ago [6-10]. The southern Appalachian Mountains are a well-known center of endemism for salamanders and other amphibians [11,12]. However, there is increasing evidence of short-range endemism in other groups, including dead wood-associated forest invertebrates (e.g., millipedes [13,14], cockroaches [15,16], and centipedes [17]).

\subsection{Subterranean Termites: Functionally Important Ecosystem Service Providers in Temperate Forests}

Dead-wood-dependent (saproxylic) arthropods play critical roles in maintaining healthy, productive forests by contributing to the decomposition of fallen trees and thus driving nutrient cycling that affects organisms at all trophic levels [18-22]. Indeed, rotting logs may be one of the most stable, thermally buffered, above-ground microhabitats that exist in forests, and the decomposition process has successional stages, facilitated by wood-feeding and wood-boring invertebrates [21,23]. Termites are some of the first to colonize a rotting log, and through feeding and tunneling activities of the worker caste, the dead-wood substrate is modified by the creation of galleries. Once established, these facilitate colonization by larger wood-feeding invertebrates [24]. Ultimately, the ecosystem engineering activities of termites contribute to enhancing the internal heterogeneity of logs, making them habitable by a diverse array of saproxylic species.

Termites in the genus Reticulitermes (Blattodea: Rhinotermitidae) are broadly distributed across the eastern United States. Morphological separation of species is notoriously difficult [25], particularly given that only the worker caste can usually be readily sampled. To address this, we developed an efficient molecular assay (i.e., polymerase chain reaction (PCR) amplification of a short region of mitochondrial cytochrome oxidase subunit II (COII) gene, followed by screening of restriction-fragment-length polymorphism (RFLP) banding profiles [26]) that can be used to distinguish each of the five eastern United States species. In the southern Appalachians, several Reticulitermes species can co-occur locally. However, true syntopy (i.e., two species co-inhabiting the same rotting log) appears to be very rare, but reported instances of fine-scale sampling have been limited.

\subsection{Ecological Niche Models: Efficient Tools for Predicting Organismal Distributions}

Ecological niche models (ENMs) are broadly useful spatially explicit analytical tools that relate species occurrence data with environmental variables, such as climatic temperature and precipitation data [27], or topographic and land cover data. Once constructed, ENMs generate maps of estimated habitat suitability, and can be used to describe the historical, current, and future climate space for a given species. For example, ENMs have been used to identify areas of high conservation importance [28-30], predict climate change effects on geographic ranges of species [31,32], as well as determine potential threats of invasive species $[33,34]$. These analytical tools are becoming widely used owing to the increasing accessibility of climatic data via public databases [35-37]. An important assumption when using ENMs to predict historical or future distributions is niche conservatism (i.e., the stability of ecological niches over time) [38]. However, evidence suggests that niche conservatism is common among closely related species [39-41], and the risks of erroneous inferences are further reduced when focusing only on contemporary climate and occurrence data (i.e., when reconstructing present-day ENMs).

\subsection{The Current State of Knowledge about Subterranean Termite Distributions, and Goals of this Study}

There is a general lack of data on the natural distributions of termites in temperate forests, given that most research has focused on damage that termites cause to man-made wooden structures. Accordingly, occurrence records mostly come from urban areas, and they are also of low resolution (e.g., presence/absence in a given county). Notwithstanding these limitations, Maynard et al. [42] recently provided valuable insights into the role of climatic (temperature and precipitation) variables in influencing distributions of termites in the eastern United States. Specifically, those authors 
performed ENM for two Reticulitermes species (R. flavipes and R. virginicus) and the invasive Formosan subterranean termite, Coptotermes formosanus. Furthermore, they synthesized pre-existing knowledge to identify the influence on termite distributions of biotic factors, such as tree species and wood traits, fungal preferences, phenology of predatory ants, and competitive asymmetries among coexisting termite species. While interspecific competition may result in spatial or temporal separation which could lead to niche divergence, to date, very little is known about niche partitioning in subterranean termites and the environmental factors that may lead to niche divergence.

In the present paper, we aimed to generate new insights into regional-scale environmental drivers of geographic distributions of termite species, and how these environmental factors impact co-occurrence among congeneric species. Focusing on the southern Appalachian Mountains and surrounding areas, we performed an ENM-based evaluation of niche divergence among the three most common Reticulitermes species in the eastern United States. In addition to identifying niche divergence, if present, we aimed to determine the environmental factors driving niche divergence among species.

\section{Materials and Methods}

\subsection{Termite Sampling, Species Identification, and Ecological Niche Modeling}

From 2012 to 2016, we collected Reticulitermes termites from 132 sites across the southern Appalachians Mountains and surrounding areas (Table S1; Figure S1). At most sites, termite workers were collected from a single rotting $\log$ at an intermediate to late stage of decay. However, at 10 sites, termites were also collected from additional logs within $\sim 30 \mathrm{~m}$ of one another (i.e., samples came from a total of $2 \operatorname{logs}$ at 8 sites, $3 \operatorname{logs}$ at 1 site, and 4 logs at 1 site; Table S1). Owing to the close proximity of these clustered logs (i.e., at or near the typical error associated with a handheld GPS unit), the same coordinates were assigned to them, but specimen collections were assigned log-specific identifiers. Molecular taxonomic identifications were based on a single termite per rotting $\log$, using Garrick et al.'s [26] PCR-RFLP assay. Briefly, a short (376-bp) region of the mitochondrial COII gene was amplified (using PCR primers RetCo2-F and RetCo2-R), and products were then sequentially digested with three restriction enzymes (RsaI, TaqI, and MspI), which in combination generate diagnostic species-specific banding patterns. Ultimately, we identified 91 non-redundant occurrence points for $R$. flavipes, 30 for $R$. virginicus, and 17 for $R$. malletei (Table S1). ENM was conducted with the 'biomod2' package [43] in R [44] using four modeling algorithms (e.g., [45-47]). Distributions were reconstructed using mean climatological data for a period spanning 1960-1990, with all variables used at 1-km resolution. Nineteen bioclimatic variables [35] were obtained from the WorldClim database v.1.4 (http:/ / www.worldclim.org), and then factor analysis was used to reduce the number of predictors, and the associated correlation among them (see Files S1 for full details of ENM methods). From the 19 bioclimatic variables, we generated four environmental factors (see File S1 and Figures S2 and S3 for full details of factor analysis): dry-season precipitation, wet-season precipitation, summer temperature, and temperature range.

\subsection{Niche Occupancy, Niche Identity, and Distributional Overlap}

Predicted niche occupancy profiles were generated for each environmental factor following Evans et al. [48], implemented in the 'phyloclim' package [49]. Niche overlap for each environmental factor was summarized using both Schoener's D statistic [50], and the modified Hellinger statistic, I, as proposed by Warren et al. [51]. We also used the D and I statistics to determine pairwise niche equivalency/identity among the three Reticulitermes species. The niche equivalency test asks whether the ENMs of two species are more different than expected if they had been drawn from the same distribution. To perform the niche equivalency test, we generated a distribution using 999 pseudoreplicate datasets.

To assess distributional overlap based on ENMs, we used maps of binary presence/absence as well as continuous occurrence probabilities. We used binary predictions, because this allowed 
us to determine which species co-occurred in areas of distributional overlap. However, since the use of continuous predictions has been recommended when estimating species richness [52], we calculated the sum of Reticulitermes species' occurrence probabilities (Figure S4), and calculated joint and exclusive occurrence probabilities for each of the three species (Figure S5). For binary predictions, the approach of maximizing sensitivity and specificity has consistently performed better than other methods [53-55]. Thus, we used the True Skill Statistic (TSS = sensitivity + specificity -1 ) [56] both as a model performance metric and to identify a threshold for converting continuous occurrence probabilities to binary classifications. The threshold was chosen based on maximizing the TSS, without risking under-prediction of presences (i.e., selecting the lowest threshold at which TSS is maximized). We used a threshold value of 0.2 , where probability $>0.2$ represented presence, and suitability $\leq 0.2$ represented absence. We merged the three species' binary maps by summing re-coded maps, where absence $=0$, but presence was coded depending on species: $R$. flavipes $=4, R$. virginicus $=2$, and R. malletei $=1$. This way, the sum of binary maps resulted in seven distinct categories: single-species areas ( 3 categories, with aforementioned scores); areas of two-species overlap ( 3 categories, scores of either 3,5 , or 6 depending on the identity of the species pair); and areas where all three species overlap (1 category, with a score of 7 ).

\subsection{Environmental Factors and Niche Divergence}

To determine the sources of variation in the Reticulitermes occurrence dataset, we included the effects of spatial structure and environmental factors, and performed variance partitioning using the 'varpart' function in 'vegan' [57]. To account for multiple predictors in the model, we used adjusted $\mathrm{R}^{2}$. To determine which (if any) environmental factors have significantly contributed to niche divergence of Reticulitermes species, we first removed the effect of spatial structure. We did this by performing distance-based redundancy analysis [58] using the 'capscale' function. To account for spatial structure, we transformed Euclidean geographic distances to a continuous rectangular vector by Principal Coordinates analysis of Neighbor Matrices (PCNM) using the 'pcnm' function in 'vegan'. Only significant PCNM axes were used in partialling out spatial structure. Significance of the environmental and spatial predictors was assessed using multivariate F-statistics with 9999 permutations.

\section{Results}

\subsection{Niche Occupancy, Niche Identity, and Distributional Overlap}

Predicted niche occupancy profiles for the three Reticulitermes species (Figure 1) showed differences in peak values across all four environmental factors. The two temperature factors, summer temperature and temperature range, showed differences in peaks between $R$. flavipes and $R$. virginicus, whereas R. malletei was intermediate. Similarly, the two precipitation factors, dry-season precipitation and wet-season precipitation, showed more marked differences between $R$. flavipes and $R$. virginicus than for any of the other pairwise species comparisons. The bimodality of summer temperature and wet-season precipitation is a result of occurrence of Reticulitermes species in two areas with pronounced differences in wet-season precipitation (see Figure S3). Bimodality was also observed for summer temperature in $R$. flavipes, given that the species occurs in both low elevations and the cooler high-elevation areas of the Appalachians (see Figure S3). Statistics that characterize the extent of niche overlap showed that $R$. flavipes and $R$. virginicus had the least amount of overlap $(\mathrm{D}=0.582$, $\mathrm{I}=0.843$; Table 1). Furthermore, the niche identity test between these two species showed significant differentiation $(p<0.001$; Table 1). R. malletei was more similar to $R$. flavipes in terms of temperature range $(\mathrm{D}=0.889)$ and summer temperature $(\mathrm{D}=0.872)$, but showed more overlap with $R$. virginicus for dry- $(\mathrm{D}=0.894)$ and wet-season precipitation $(\mathrm{D}=0.848)$. $R$. virginicus showed the least overlap with $R$. flavipes, across all four environmental factors (Table 2). 

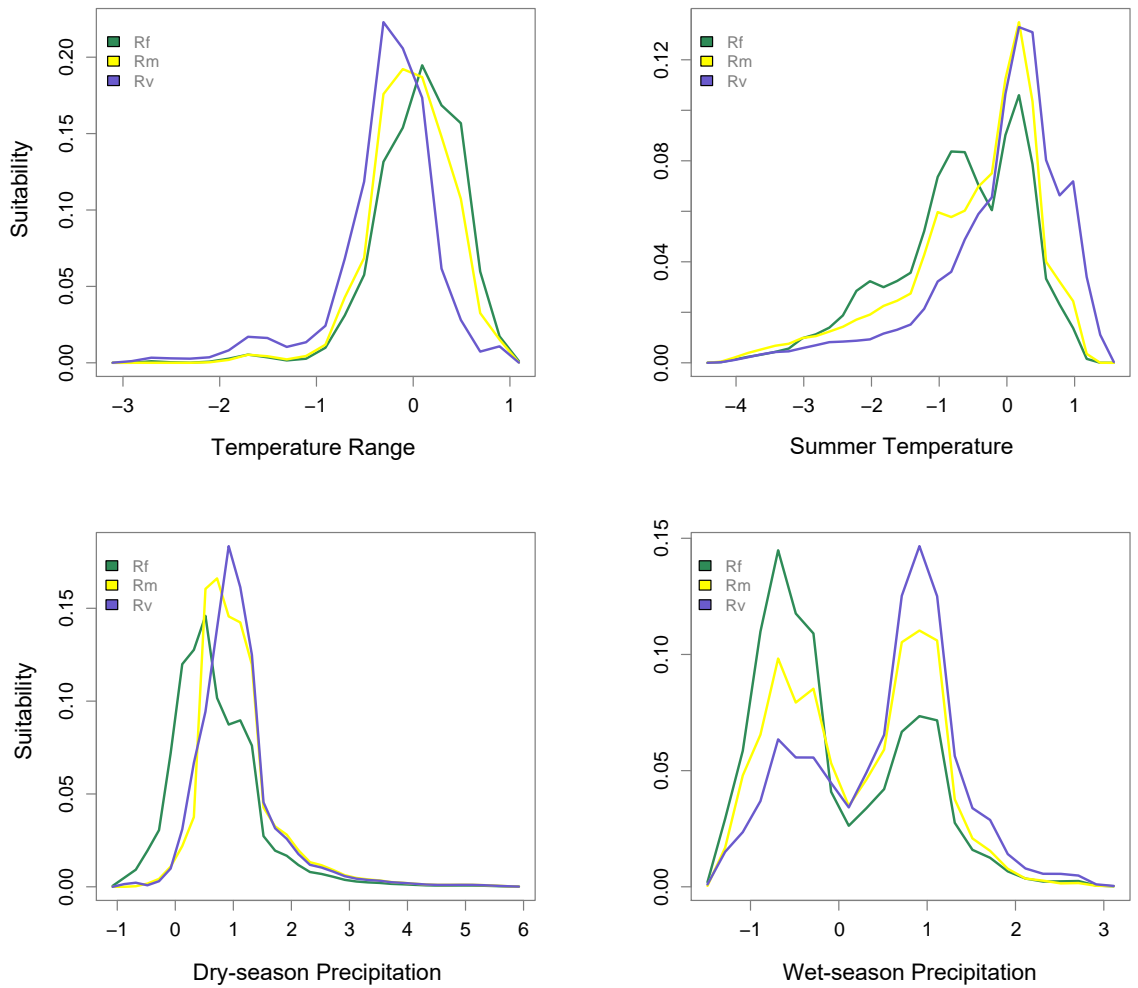

Figure 1. Predicted niche occupancy. Four environmental factors were used to estimate niche occupancy of $R$. flavipes (Rf), R. malletei (Rm), and R. virginicus (Rv): top two panels: temperature range and summer temperature; bottom two panels: dry- and wet-season precipitation. The y-axis represents niche occupancy, or suitability, and the area under the curves sums to 1, the total suitability.

Table 1. Niche identity test. The upper off-diagonal shows Schoener's D statistic, and the lower off-diagonals shows the modified Hellinger statistic, I. Significant niche divergence is reported in bold text with red highlighting. The more dissimilar of the other two niche comparisons is highlighted in pink. Abbreviations used for R. flavipes, R. malletei, and R. virginicus are Rf, $\mathrm{Rm}$, and $\mathrm{Rv}$, respectively.

\begin{tabular}{cccc}
\hline & $\mathrm{Rf}$ & $\mathrm{Rm}$ & $\mathrm{Rv}$ \\
\hline \multirow{2}{*}{$\mathrm{Rf}$} & - & $\mathrm{D}=0.744$ & $\mathrm{D}=\mathbf{0 . 5 8 2}$ \\
& & $p=0.280$ & $p<0.001$ \\
\hline \multirow{2}{*}{$\mathrm{Rm}$} & $\mathrm{I}=0.935$ & & $\mathrm{D}=0.788$ \\
& $p=0.239$ & - & $p=0.630$ \\
\hline \multirow{2}{*}{$\mathrm{Rv}$} & $\mathrm{I}=\mathbf{0 . 8 4 3}$ & $\mathrm{I}=0.961$ & - \\
& $p<0.001$ & $p=0.750$ & \\
\hline
\end{tabular}

Table 2. Pairwise niche overlap among Reticulitermes species for each of four environmental factors. The top three rows show Schoener's D statistic, and the bottom three rows show the modified Hellinger statistic, I. The four environmental factors are: temperature range (TR), summer temperature (ST), dry-season precipitation (DP), and wet-season precipitation (WP). Niche overlap is highest in green and lowest in red. $R$. flavipes, $R$. malletei, and $R$. virginicus are abbreviated as $\mathrm{Rf}, \mathrm{Rm}$, and $\mathrm{Rv}$, respectively.

\begin{tabular}{cccccc}
\hline & & TR & ST & DP & WP \\
\hline \multirow{4}{*}{ D } & $\mathrm{Rf} / \mathrm{Rm}$ & 0.889 & 0.872 & 0.693 & 0.820 \\
& $\mathrm{Rf} / \mathrm{Rv}$ & 0.683 & 0.707 & 0.680 & 0.680 \\
& $\mathrm{Rm} / \mathrm{Rv}$ & 0.791 & 0.809 & 0.894 & 0.848 \\
\hline \multirow{3}{*}{ I } & $\mathrm{Rf} / \mathrm{Rm}$ & 0.991 & 0.990 & 0.919 & 0.982 \\
& $\mathrm{Rf} / \mathrm{Rv}$ & 0.917 & 0.928 & 0.926 & 0.942 \\
& $\mathrm{Rm} / \mathrm{Rv}$ & 0.952 & 0.961 & 0.990 & 0.984 \\
\hline
\end{tabular}


The predicted distribution of $R$. flavipes spanned a larger area in the northern portion of the southern Appalachians than that of the other two species. R. flavipes overlapped with $R$. malletei, to the exclusion of R. virginicus, in an area including Kentucky, Virginia, and West Virginia (Figure 2; Figure S5). The overlap between $R$. flavipes and $R$. virginicus, excluding $R$. malletei, spanned a smaller area, with lower probability (Figure S5). Predicted distributions of all three species overlapped in eastern Tennessee, western North Carolina, northern Alabama and Georgia (Figure 2; Figures S4 and S5).

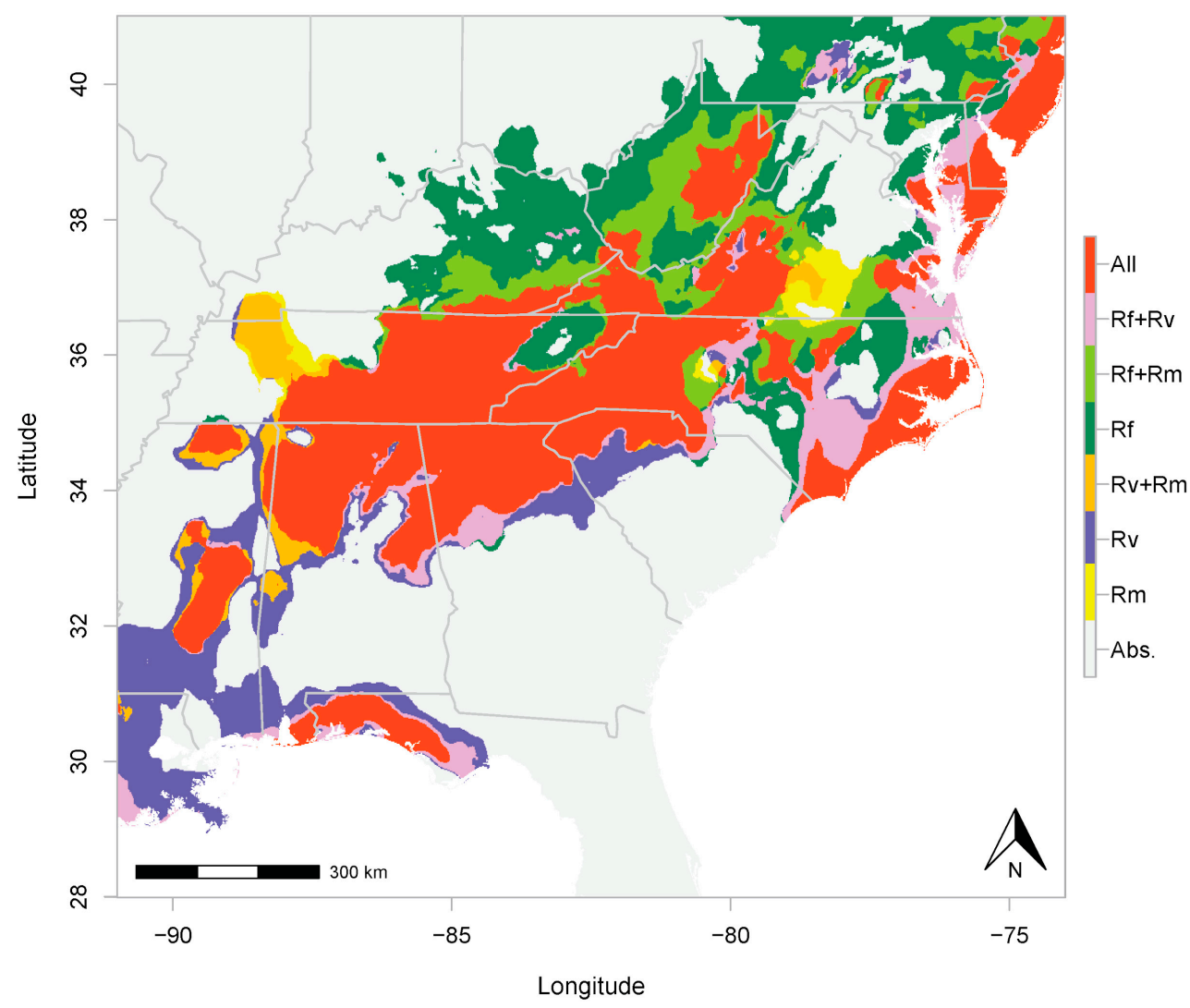

Figure 2. Distributional overlap of R. flavipes (Rf), R. malletei (Rm), and R. virginicus (Rv). Overlap is color coded based on the number of species. "All" is where occurrence of all three species is predicted. Areas of two-species overlap are shown in the legend as " $\mathrm{Rf}+\mathrm{Rv}$ ", " $\mathrm{Rf}+\mathrm{Rm}$ ", and " $\mathrm{Rv}+\mathrm{Rm}$ ". Absence of all three species is shown in grey and referred to in the legend as "Abs."

\subsection{Environmental Factors and Niche Divergence}

Distance-based redundancy analysis (Figure 3) showed that only the summer temperature factor contributed significantly $\left(\mathrm{F}_{1,127}=8.673, p=0.001\right)$ to differences in occurrence among the three Reticulitermes species. After accounting for spatial structure by partialling out six significant spatial components (PCNM axes 1, 4, 6, 17, 43, and 58), summer temperature remained significant $\left(\mathrm{F}_{1,121}=5.622, p=0.003\right)$. The six significant spatial components along with summer temperature accounted for $18.5 \%$ of the observed variation in the occurrence data. Spatial structure alone explained $9.6 \%$ of the variation, environmental factors accounted for $3.3 \%$, and the interaction between the two explained an additional $5.6 \%$ of the variation.

Following the removal of spatial structure effects, the highest correlation coefficient between environmental factors and ordination axes of the distance-based redundancy analysis was observed for summer temperature $(\mathrm{r}=0.730)$ and axis 1 . This axis captured the divergence of $R$. virginicus from the other two species (Figure 3). Thus, summer temperature contributed significantly to $R$. virginicus 
divergence. While not significant, temperature range $(\mathrm{r}=-0.383)$ and wet-quarter precipitation $(\mathrm{r}=0.376)$ were correlated with axis 2 , which captured the divergence of $R$. malletei (Figure 3).

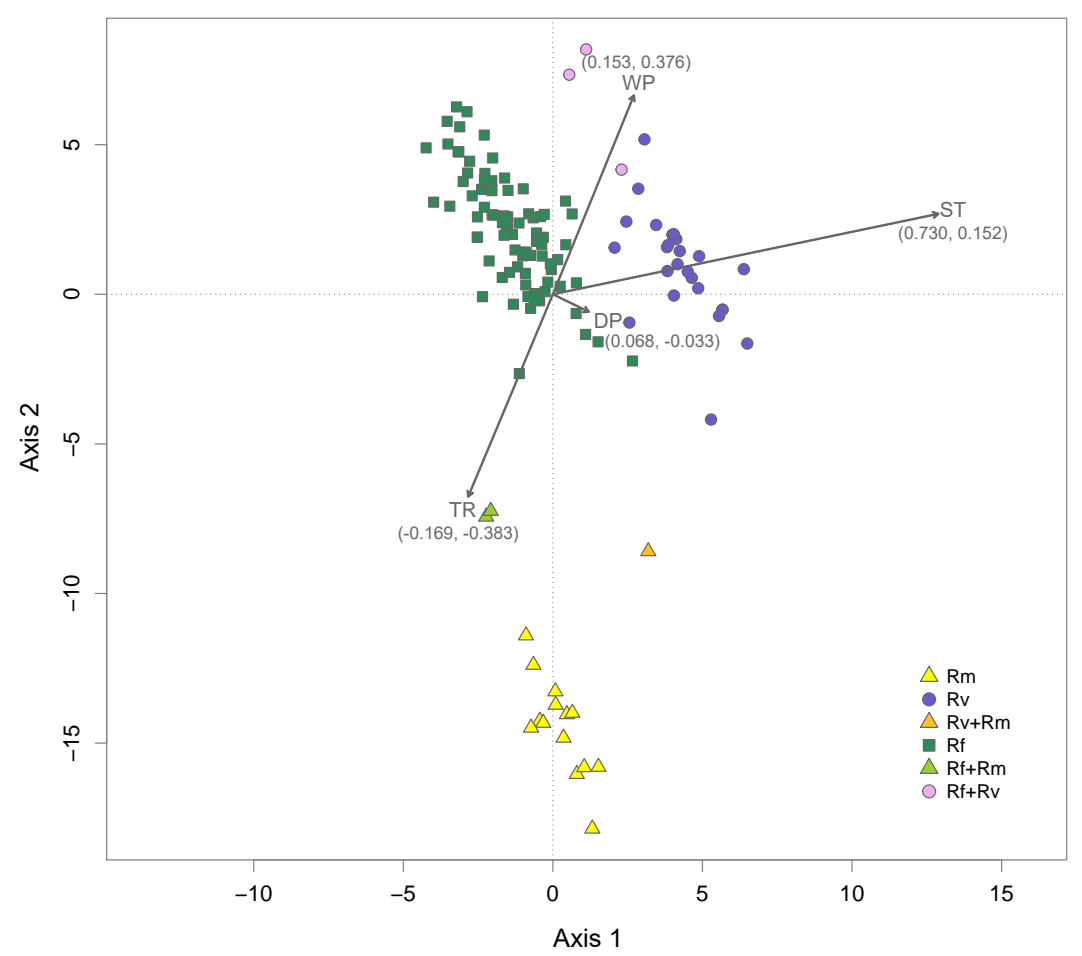

Figure 3. Distance-based redundancy analysis. The plot shows a constrained ordination of 132 sampling sites, color coded based on the number of species present. Sites where only R. flavipes, $R$. virginicus, or $R$. malletei were sampled are referred to in the legend as " $\mathrm{Rf}^{\prime}$, " $\mathrm{Rv}$ ", and "Rm", respectively. Two-species sites are shown in the legend as " $R f+R v$ ", " $R f+R m$ ", and " $R v+R m$ ". The ordination is conditional on six significant spatial components (PCNM axes 1, 4, 6, 17, 43, and 58) and constrained by four environmental factors: dry-season precipitation (DP); wet-season precipitation (WP); summer temperature (ST); temperature range (TR). Arrows show strength of correlation (coefficients in parentheses) of environmental factors with ordination axes 1 and 2.

\section{Discussion}

This study provides insights into the ecology of subterranean termites with regard to geographic distributions and niche partitioning among three broadly co-distributed Reticulitermes species in the southern Appalachian Mountains and surrounding areas. This region is a biogeographically significant center of endemism, yet the ecology of its resident invertebrate fauna-particularly saproxylic insects-is poorly known. Our ENMs suggest that an area in the mid-latitudes of the southern Appalachians, characterized by complex topography and multiple ecoregions, provides suitable habitat to support all three Reticulitermes species. Our study also highlights the roles that temperature and precipitation play in driving niche divergence among Reticulitermes species. To our knowledge, this work represents the first evidence of significant regional-scale niche divergence between $R$. flavipes and $R$. virginicus. Below, we consider the broader context of these findings, as well as caveats and future directions for follow-up studies that build on the information presented here.

\subsection{Reticulitermes Distributions and Climatic Drivers of Niche Divergence among Species}

Our analyses predicted extensive co-occurrence of all three Reticulitermes species in the mid-latitudes of the southern Appalachians (Figure 2; Figures S4 and S5). Based on paleoclimatic [59], biogeographic [60] and comparative phylogeographic [61] data, the southern Appalachians remained 
free from Pleistocene ice sheets and served as a major refuge for many species during glacial periods, consequently maintaining higher levels of biodiversity. Indeed, the present-day complexity of this mid-latitude region harbors many different niches, which could facilitate long-term coexistence of closely related species. However, in addition to predicted co-occurrence of Reticulitermes species in the montane regions of the southern Appalachians, our ENMs also identified areas of two- and three-species co-occurrence along the Gulf coast of western Florida, and the Atlantic coast from North Carolina to New Jersey and New York. To empirically confirm the co-occurrence of subterranean termites in these coastal areas, future studies should include these regions in their sampling efforts. In the case of another forest-dependent invertebrate, the millipede Narceus americanus, the Florida Gulf coast has been identified as an important refuge during the Last Glacial Maximum [62]. Indeed, the paleoclimatic history of areas to the south and east of the southern Appalachian Mountains are increasingly being recognized as reservoirs of forest invertebrate biodiversity during past periods of environment change. The incidence of high termite species diversity-even though only assessed here for one genus-is therefore not unexpected.

In addition to co-occurrence of Reticulitermes species, our study provides novel insights into climatic drivers of niche divergence. Consistent with the findings of Maynard et al. [42], we determined that $R$. virginicus is more restricted to the south, whereas $R$. flavipes has a broad latitudinal range. Furthermore, we determined that $R$. flavipes occurs farther north than the other two species, even excluding other Reticulitermes (Figure S5), potentially because it tolerates lower amounts of precipitation (both dry- and wet-season; Figure 1). Maynard et al.'s [42] ENMs showed that temperature variables were the most important predictors of termite distributions. Based on our formal assessment of niche overlap between $R$. flavipes and $R$. virginicus, we determined that both temperature and precipitation seasonality (as represented by temperature range, summer temperature, and dry- and wet-season precipitation) play non-negligible roles in the significant niche divergence between $R$. flavipes and $R$. virginicus. Furthermore, using distance-based redundancy analysis, we identified summer temperature as a major driver of this divergence, with $R$. flavipes occurring in areas with lower summer temperatures. In the mid-latitudes of the southern Appalachians, where dry-season precipitation is high (Figure S3), all three Reticulitermes species co-occur (Figure 2; Figures S4 and S5), but farther north, where dry- and wet-season precipitation is low (Figure S3), $R$. flavipes is more competitive.

\subsection{Potential Explanations for Lack of Empirical Evidence for Local-Scale Coexistence of Reticulitermes Species}

Interestingly, despite the significant niche divergence between $R$. flavipes and $R$. virginicus, we collected both of these species from the same rotting log at one sampling site (i.e., \#37 located near the Georgia/Southern Carolina state border; Table S1). To our knowledge, this is the first record of true syntopy between Reticulitermes species. The apparent rarity of syntopy and general lack of coexistence of Reticulitermes species at local scales could be explained by competitive exclusion. Colony size and soldier number are important features for termite competitive ability. Termite species with small colonies have been observed to relinquish resources and be eliminated by dominant interspecific competitors with large colonies [63]. Through avoidance of dominant competitors, interspecific competition may result in spatial separation [64], but also temporal separation (i.e., phenological differences). Termites may be able to avoid other related species using vibrational cues. Indeed, vibrational cues are important for termite sensory perception and communication, as these signals can travel over long distances $[65,66]$. For instance, the drywood termite Cryptotermes secundus can distinguish conspecifics from the dominant competitor in the environment, the subterranean termite Coptotermes acinaciformis [65]. Furthermore, Coptotermes acinaciformis detects its major predator, the ant Iridomyrmex purpureus, using vibrational cues only [66]. Overall, given these highly tuned sensory capabilities, it stands to reason that competitive exclusion, or competitor avoidance, could be important factors in preventing local co-occurrence among Reticulitermes species. Alternatively, the dominant competitor may ultimately outcompete the other species. For instance, $R$. flavipes 
has a broad distribution and occurs farther north than the other two species, possibly due to a competitive advantage stemming from the fact that it tolerates conditions of lower dry- and wet-season precipitation. Furthermore, interspecific aggression coupled with low levels of intraspecific agonism (even colony fusion) $[67,68]$, may make $R$. flavipes the dominant competitor.

\subsection{Caveats and Future Directions}

While our sampling suggests that true syntopy and local co-occurrence of different species at the same site is very rare, our detection of only one species in all but one rotting log, and at the majority of sampling sites (i.e., 126 out of 132), may actually be a consequence of the sampling strategy that was employed (see Section 2.1). Briefly, we simply aimed to collect termites from each site, rather than provide a complete assessment of termite diversity at each site. Indeed, variance partitioning reflects this, showing that most $(81.5 \%)$ of the variance in the occurrence data did not stem from spatial structure $(9.6 \%)$, or environmental differences $(3.3 \%)$, or interaction between the two (5.6\%). Accordingly, while competitive exclusion is a plausible explanation for apparent rare local-scale co-occurrence (i.e., micro-allopatry) among Reticulitermes species, a dedicated sampling approach would be required to formally test this idea. For example, exhaustively sampling multiple logs per site, at a series of sites arranged along a transect traversing a region where two or more species occur in close proximity would be a productive approach. Fortunately, the present study identified specific geographic areas where future assessments of the frequency of true syntopy vs. micro-allopatry, and associated interspecific competitive interactions, should be focused (Table S1; Figure S1).

Although we have shown separation in niche space between species, particularly $R$. flavipes and $R$. virginicus, these inferences were underpinned by regional-scale environmental variables, and so they do not take into account local-scale drivers of niche divergence such as differences in microhabitat preference, phenology, or diet. Indeed, Maynard et al. [42] highlighted that biotic and soil characteristics play a role in termite distribution and abundance. Thus, our assessment of niche divergence is necessarily incomplete. While it does provide important baseline information, follow-up studies of local-scale drivers of species' distributions could examine aspects of the microhabitat (e.g., humidity and temperature of soil and rotting logs), timing of nuptial flights along latitudinal and altitudinal clines, and/or use stable isotopes to determine decomposition stage of ingested wood and the importance of microbial biomass in termite diets at a given location [69].

Supplementary Materials: The following are available online at http:/ /www.mdpi.com/2075-4450/10/1/33/s1, File S1: Environmental variables and Ecological Niche Modeling methods; Table S1: Sampling sites with number of species occurrences at each site and number of logs per site; Figure S1: Map of Reticulitermes sampling depicting occurrences of one or more species at each site; Figure S2: Factor analysis; Figure S3: Environmental factors and bioclimatic variables; Figure S4: Distributional overlap of Reticulitermes species; Figure S5: Probability of joint and exclusive occurrence of Reticulitermes species.

Author Contributions: Both authors conceived the study, and collected and curated samples; C.H. performed lab work, analyzed the data, and wrote the first draft; both authors edited subsequent drafts.

Funding: This work was supported by grants from the American Philosophical Society, Bay and Paul Foundations, Eppley Foundation for Research, National Geographic Society, Washington Biologists' Field Club, and start-up funds from the University of Mississippi.

Acknowledgments: We thank three anonymous reviewers whose valuable comments helped improve the manuscript. We thank R.J. Dyer, R.E. Symula, and E.W. Collier for their assistance with field work, and B.C. Collins for his contribution to lab work. Scientific collecting permits were provided by the Alabama Department of Conservation and Natural Resources, Georgia Department of Natural Resources (permit number 29-WBH-12-16), United States Department of Agriculture Forest Service, and United States National Park Service (permit numbers GRSM-2012-SCI-2242, SHEN-2012-SCI-0015, and CUGA-2012-SCI-0008).

Conflicts of Interest: The authors declare no conflict of interest. 


\section{References}

1. Clark, S.H.B. Birth of the Mountains: The Geologic Story of the Southern Appalachian Mountains; USGS Reports; US Government Printing Office: Washington, DC, USA, 2001.

2. Pittillo, J.D.; Hatcher, R.D.; Buol, S.W. Introduction to the environment and vegetation of the southern Blue Ridge Province. Castanea 1998, 63, 202-216.

3. Hayes, M.; Moody, A.; White, P.S.; Costanza, J.L. The influence of logging and topography on the distribution of spruce-fir forests near their southern limits in Great Smoky Mountains National Park, USA. Plant Ecol. 2007, 189, 59-70. [CrossRef]

4. Whittaker, R.H. Vegetation of the Great Smoky Mountains. Ecol. Monogr. 1956, 26, 1-80. [CrossRef]

5. Jackson, B.C.; Pittillo, J.D.; Allen, H.L.; Wentworth, T.R.; Bullock, B.P.; Loftis, D.L. Species diversity and composition in old growth and second growth rich coves of the southern Appalachian Mountains. Castanea 2009, 74, 27-38. [CrossRef]

6. Bennett, K.D. The spread of Fagus grandifolia across Eastern North America during the last 18000 years. J. Biogeogr. 1985, 12, 147-164. [CrossRef]

7. Bennett, K.D. The rate of spread and population increase of forest trees during the postglacial. Philos. Trans. R. Soc. Lond. B Biol. Sci. 1986, 314, 523-531. [CrossRef]

8. Delcourt, H.R.; Delcourt, P.A. Quaternary landscape ecology: Relevant scales in space and time. Landsc. Ecol. 1988, 2, 23-44. [CrossRef]

9. Williams, J.W.; Post, D.M.; Cwynar, L.C.; Lotter, A.F.; Levesque, A.J. Rapid and widespread vegetation responses to past climate change in the North Atlantic region. Geology 2002, 30, 971-974. [CrossRef]

10. Williams, J.W.; Shuman, B.N.; Webb, T., III; Bartlein, P.J.; Leduc, P.L. Late-Quaternary vegetation dynamics in North America: Scaling from taxa to biomes. Ecol. Monogr. 2004, 74, 309-334. [CrossRef]

11. Petranka, J.W. Salamanders of the United States and Canada; Smithsonian Institution Press: Washington, DC, USA, 1998.

12. Rissler, L.J.; Smith, W.H. Mapping amphibian contact zones and phylogeographical break hotspots across the United States. Mol. Ecol. 2010, 19, 5404-5416. [CrossRef]

13. Snyder, B.A. A preliminary checklist of the millipedes (Diplopoda) of the Great Smoky Mountains National Park, USA. Zootaxa 2008, 1856, 16-32.

14. Marek, P.E. A revision of the Appalachian millipede genus Brachoria Chamberlin, 1939 (Polydesmida: Xystodesmidae: Apheloriini). Zool. J. Linn. Soc. 2010, 159, 817-889. [CrossRef]

15. Nalepa, C.A.; Shimada, K.; Maekawa, K.; Luykx, P. Distribution of karyotypes of the Cryptocercus punctulatus species complex (Blattodea: Cryptocercidae) in Great Smoky Mountains National Park. J. Insect Sci. 2017, 17, 69. [CrossRef] [PubMed]

16. Garrick, R.C.; Sabree, Z.L.; Jahnes, B.C.; Oliver, J.C. Strong spatial-genetic congruence between a wood-feeding cockroach and its bacterial endosymbiont, across a topographically complex landscape. J. Biogeogr. 2017, 44, 1500-1511. [CrossRef]

17. Garrick, R.C.; Newton, K.E.; Worthington, R.J. Cryptic diversity in the southern Appalachian Mountains: Genetic data reveal that the red centipede, Scolopocryptops sexspinosus, is a species complex. J. Insect Sci. 2018, 22, 799-805. [CrossRef]

18. Ulyshen, M.D. Strengthening the case for saproxylic arthropod conservation: A call for ecosystem services research. Insect Conserv. Divers. 2013, 6, 393-395. [CrossRef]

19. Ulyshen, M.D. Interacting effects of insects and flooding on wood decomposition. PLoS ONE 2014, 9, e101867. [CrossRef] [PubMed]

20. Ulyshen, M.D. Insect-mediated nitrogen dynamics in decomposing wood. Ecol. Entomol. 2015, 40, 97-112. [CrossRef]

21. Ulyshen, M.D. Wood decomposition as influenced by invertebrates. Biol. Rev. 2016, 91, 70-85. [CrossRef] [PubMed]

22. Ulyshen, M.D.; Wagner, T.L. Quantifying arthropod contributions to wood decay. Methods Ecol. Evol. 2013, 4, 345-352. [CrossRef]

23. Stokland, J.N.; Siitonen, J.; Jonsson, B.G. Biodiversity in Dead Wood; Cambridge University Press: Cambridge, UK, 2012. 
24. Harmon, M.E.; Franklin, J.F.; Swanson, F.J.; Sollins, P.; Gregory, S.V.; Lattin, J.D.; Anderson, N.H.; Cline, S.P.; Aumen, N.G.; Sedell, J.R.; et al. Ecology of coarse woody debris in temperate ecosystems. In Advances in Ecological Research; MacFadyen, A., Ford, E.D., Eds.; Academic Press: Cambridge, MA, USA, 1986; Volume 15, pp. 133-302.

25. Lim, S.Y.; Forschler, B.T. Reticulitermes nelsonae, a new species of subterranean termite (Rhinotermitidae) from the Southeastern United States. Insects 2012, 3, 62-90. [CrossRef] [PubMed]

26. Garrick, R.C.; Collins, B.D.; Yi, R.N.; Dyer, R.J.; Hyseni, C. Identification of eastern United States Reticulitermes termite species via PCR-RFLP, assessed using training and test data. Insects 2015, 6, 524-537. [CrossRef] [PubMed]

27. Elith, J.; Leathwick, J.R. Species distribution models: Ecological explanation and prediction across space and time. Annu. Rev. Ecol. Evol. Syst. 2009, 40, 677-697. [CrossRef]

28. Kabir, M.; Hameed, S.; Ali, H.; Bosso, L.; Din, J.U.; Bischof, R.; Redpath, S.; Nawaz, M.A. Habitat suitability and movement corridors of grey wolf (Canis lupus) in Northern Pakistan. PLoS ONE 2017, 12, e0187027. [CrossRef] [PubMed]

29. Miličić, M.; Vujić, A.; Jurca, T.; Cardoso, P. Designating conservation priorities for Southeast European hoverflies (Diptera: Syrphidae) based on species distribution models and species vulnerability. Insect Conserv. Divers. 2017, 10, 354-366. [CrossRef]

30. Bosso, L.; Smeraldo, S.; Rapuzzi, P.; Sama, G.; Garonna, A.P.; Russo, D. Nature protection areas of Europe are insufficient to preserve the threatened beetle Rosalia alpina (Coleoptera: Cerambycidae): Evidence from species distribution models and conservation gap analysis. Ecol. Entomol. 2018, 43, 192-203. [CrossRef]

31. Da Mata, R.A.; Tidon, R.; de Oliveira, G.; Vilela, B.; Diniz-Filho, J.A.F.; Rangel, T.F.; Terribile, L.C. Stacked species distribution and macroecological models provide incongruent predictions of species richness for Drosophilidae in the Brazilian savanna. Insect Conserv. Divers. 2017, 10, 415-424. [CrossRef]

32. Macfadyen, S.; McDonald, G.; Hill, M.P. From species distributions to climate change adaptation: Knowledge gaps in managing invertebrate pests in broad-acre grain crops. Agric. Ecosyst. Environ. 2018, 253, 208-219. [CrossRef]

33. Kriticos, D.J.; Kean, J.M.; Phillips, C.B.; Senay, S.D.; Acosta, H.; Haye, T. The potential global distribution of the brown marmorated stink bug, Halyomorpha halys, a critical threat to plant biosecurity. J. Pest Sci. 2017, 90, 1033-1043. [CrossRef]

34. Barbet-Massin, M.; Rome, Q.; Villemant, C.; Courchamp, F. Can species distribution models really predict the expansion of invasive species? PLOS ONE 2018, 13, e0193085. [CrossRef]

35. Hijmans, R.J.; Cameron, S.E.; Parra, J.L.; Jones, P.G.; Jarvis, A. Very high resolution interpolated climate surfaces for global land areas. Int. J. Climatol. 2005, 25, 1965-1978. [CrossRef]

36. Kriticos, D.J.; Webber, B.L.; Leriche, A.; Ota, N.; Macadam, I.; Bathols, J.; Scott, J.K. CliMond: Global high-resolution historical and future scenario climate surfaces for bioclimatic modelling: CliMond: Climate surfaces for bioclimatic modelling. Methods Ecol. Evol. 2012, 3, 53-64. [CrossRef]

37. Title, P.O.; Bemmels, J.B. ENVIREM: An expanded set of bioclimatic and topographic variables increases flexibility and improves performance of ecological niche modeling. Ecography 2018, 41, 291-307. [CrossRef]

38. Araújo, M.B.; Peterson, A.T. Uses and misuses of bioclimatic envelope modeling. Ecology 2012, 93, 1527-1539. [CrossRef] [PubMed]

39. Kozak, K.H.; Wiens, J.J. Does niche conservatism promote speciation? A case study in North American salamanders. Evolution 2006, 60, 2604-2621. [CrossRef] [PubMed]

40. Peterson, A.T.; Soberon, J.; Sanchez-Cordero, V. Conservatism of ecological niches in evolutionary time. Science 1999, 285, 1265-1267. [CrossRef] [PubMed]

41. Rödder, D.; Lötters, S. Niche shift versus niche conservatism? Climatic characteristics of the native and invasive ranges of the Mediterranean house gecko (Hemidactylus turcicus). Glob. Ecol. Biogeogr. 2009, 18, 674-687. [CrossRef]

42. Maynard, D.S.; Crowther, T.W.; King, J.R.; Warren, R.J.; Bradford, M.A. Temperate forest termites: Ecology, biogeography, and ecosystem impacts. Ecol. Entomol. 2015, 40, 199-210. [CrossRef]

43. Thuiller, W.; Lafourcade, B.; Engler, R.; Araújo, M.B. BIOMOD—A platform for ensemble forecasting of species distributions. Ecography 2009, 32, 369-373. [CrossRef]

44. R Core Team. R: A Language and Environment for Statistical Computing; R Foundation for Statistical Computing: Vienna, Austria, 2018. 
45. Alarcón, D.; Cavieres, L.A. Relationships between ecological niche and expected shifts in elevation and latitude due to climate change in South American temperate forest plants. J. Biogeogr. 2018, 45, 2272-2287. [CrossRef]

46. Smeraldo, S.; Di Febbraro, M.; Bosso, L.; Flaquer, C.; Guixé, D.; Lisón, F.; Meschede, A.; Juste, J.; Prüger, J.; Puig-Montserrat, $\mathrm{X}$.; et al. Ignoring seasonal changes in the ecological niche of non-migratory species may lead to biases in potential distribution models: Lessons from bats. Biodivers. Conserv. 2018, 27, 2425-2441. [CrossRef]

47. Zacarias, D.; Loyola, R. Distribution modelling and multi-scale landscape connectivity highlight important areas for the conservation of savannah elephants. Biol. Conserv. 2018, 224, 1-8. [CrossRef]

48. Evans, M.E.K.; Smith, S.A.; Flynn, R.S.; Donoghue, M.J. Climate, niche evolution, and diversification of the "bird-cage" evening primroses (Oenothera, sections Anogra and Kleinia). Am. Nat. 2009, 173, 225-240. [CrossRef] [PubMed]

49. Heibl, C.; Calenge, C. Phyloclim: Integrating Phylogenetics and Climatic Niche Modeling; R Package Version 0.9.5; 2018.

50. Schoener, T.W. The Anolis lizards of Bimini: Resource partitioning in a complex fauna. Ecology 1968, 49, 704-726. [CrossRef]

51. Warren, D.L.; Glor, R.E.; Turelli, M. Environmental niche equivalency versus conservatism: Quantitative approaches to niche evolution. Evolution 2008, 62, 2868-2883. [CrossRef] [PubMed]

52. Calabrese, J.M.; Certain, G.; Kraan, C.; Dormann, C.F. Stacking species distribution models and adjusting bias by linking them to macroecological models. Glob. Ecol. Biogeogr. 2014, 23, 99-112. [CrossRef]

53. Liu, C.; Berry, P.M.; Dawson, T.P.; Pearson, R.G. Selecting thresholds of occurrence in the prediction of species distributions. Ecography 2005, 28, 385-393. [CrossRef]

54. Liu, C.; White, M.; Newell, G. Selecting thresholds for the prediction of species occurrence with presence-only data. J. Biogeogr. 2013, 40, 778-789. [CrossRef]

55. Liu, C.; Newell, G.; White, M. On the selection of thresholds for predicting species occurrence with presence-only data. Ecol. Evol. 2016, 6, 337-348. [CrossRef]

56. Allouche, O.; Tsoar, A.; Kadmon, R. Assessing the accuracy of species distribution models: Prevalence, kappa and the true skill statistic (TSS). J. Appl. Ecol. 2006, 43, 1223-1232. [CrossRef]

57. Oksanen, J.; Blanchet, F.G.; Friendly, M.; Kindt, R.; Legendre, P.; McGlinn, D.; Minchin, P.R.; O'Hara, R.B.; Simpson, G.L.; Solymos, P.; et al. Vegan: Community Ecology Package; R Package Version 2.5-3; 2018.

58. Legendre, P.; Anderson, M.J. Distance-based redundancy analysis: Testing multispecies responses in multifactorial ecological experiments. Ecol. Monogr. 1999, 69, 1-24. [CrossRef]

59. Loehle, C. Predicting Pleistocene climate from vegetation in North America. Clim. Past 2007, 3, $109-118$. [CrossRef]

60. Swenson, N.G.; Howard, D.J. Clustering of contact zones, hybrid zones, and phylogeographic breaks in North America. Am. Nat. 2005, 166, 581-591. [CrossRef]

61. Soltis, D.E.; Morris, A.B.; McLachlan, J.S.; Manos, P.S.; Soltis, P.S. Comparative phylogeography of unglaciated eastern North America. Mol. Ecol. 2006, 15, 4261-4293. [CrossRef] [PubMed]

62. Walker, M.J.; Stockman, A.K.; Marek, P.E.; Bond, J.E. Pleistocene glacial refugia across the Appalachian Mountains and coastal plain in the millipede genus Narceus: Evidence from population genetic, phylogeographic, and paleoclimatic data. BMC Evol. Biol. 2009, 9, 25. [CrossRef] [PubMed]

63. Leponce, M.; Roisin, Y.; Pasteels, J.M. Structure and dynamics of the arboreal termite community in New Guinean coconut plantations. Biotropica 1997, 29, 193-203. [CrossRef]

64. Hubbell, S.P. The Unified Neutral Theory of Biodiversity and Biogeography; Princeton University Press: Princeton, NJ, USA, 2001.

65. Evans, T.A.; Inta, R.; Lai, J.C.S.; Prueger, S.; Foo, N.W.; Fu, E.W.; Lenz, M. Termites eavesdrop to avoid competitors. Proc. Biol. Sci. 2009, 276, 4035-4041. [CrossRef]

66. Oberst, S.; Bann, G.; Lai, J.C.S.; Evans, T.A. Cryptic termites avoid predatory ants by eavesdropping on vibrational cues from their footsteps. Ecol. Lett. 2017, 20, 212-221. [CrossRef]

67. Perdereau, E.; Dedeine, F.; Christidès, J.-P.; Dupont, S.; Bagnères, A.-G. Competition between invasive and indigenous species: An insular case study of subterranean termites. Biol. Invasions 2011, 13, 1457-1470. [CrossRef] 
68. Perdereau, E.; Bagnères, A.-G.; Dupont, S.; Dedeine, F. High occurrence of colony fusion in a European population of the American termite Reticulitermes flavipes. Insectes Soc. 2010, 57, 393-402. [CrossRef]

69. Hyodo, F. Use of stable carbon and nitrogen isotopes in insect trophic ecology. Entomol. Sci. 2015, 18, $295-312$. [CrossRef]

(c)

(c) 2019 by the authors. Licensee MDPI, Basel, Switzerland. This article is an open access article distributed under the terms and conditions of the Creative Commons Attribution (CC BY) license (http://creativecommons.org/licenses/by/4.0/). 